\title{
Современные взгляды на диагностику метаболической кардиомиопатии вследствие хронического физического перенапряжения организма спортсменов
}

\author{
Е. Л. Михалюк, В. В. Сыволап
}

Запорожский государственный медицинский университет, Запорожье, Украина

\begin{abstract}
Резюме: Представлено огляд досліджень, присвячений діагностиці метаболічної кардіоміопатії внаслідок хронічного фізичного перенапруження (КМПФП) у спортсменів. Особливий акцент зроблено на ранній діагностиці КМПФП, заснованій на даних електрокардіографії (EKГ), ехокардіографії і результатах визначення парних тропонинів / у відповідь на дозоване велоергометричне навантаження. Обгрунтовано алгоритм діагностики, який дозволяє виявляти зустрічальність КМПФП у спортсменів у 0,39 \% випадків.

Ключові слова: спортсмени, кардіоміопатія внаслідок хронічного фізичного перенапруження, проби з фізичним навантаженням, тропонин I, діагностика.
\end{abstract}

Summary: This article provides an overview of research devoted to the diagnosis of metabolic cardiomyopathy due to chronic physical stress (KMP) in athletes. Particular emphasis is placed on early diagnosis KMP based on ECG, echocardiogram and determination of the results of paired troponin I in response to the dosage bicycle exercise load. Substantiated diagnosis algorithm that allows to diagnose, the occurrence of KMP the athletes in 0,39\% of cases.

Key words: sportsmen, cardiomyopathy as result of chronic physical stress, exercise test, troponin I, diagnostics.

Современный спорт высших достижений неразрывно связан с интенсификацией тренировочного процесса и предельными фризическими нагрузками. Весьма важно, что в олимпийском и профрессиональном спорте, где уровень врачебного контроля значительно выше, предельные фризические нагрузки (на грани возможностей человека) не исключают случаев острого и хронического фризического перенапряжения с негативными последствиями для здоровья спортсмена.

Усовершенствование инструментальных методов исследования функционального состояния спортсменов позволяет, с одной стороны, выявлять положительные сдвиги, возникающие под влиянием рациональных занятий фризкультурой и спортом, с другой, - своевременно диагностировать ряд пограничных и патологических состояний.

Известно, что чрезмерные фризические и эмоциональные нагрузки - пусковой механизм для развития цепи патологических реакций, формирующих в конечном итоге кардиомиопатию вследствие хронического фризического перенапряжения (КМПФП). Признание полипатогенетической природы КМПФП с учетом locus minoris resistentiae функциональной системы, а также многообразия клинических проявлений КМПФП, являются основой для дальнейшего углубленного изучения поражений сердца у спортсменов [10].

При всех трудностях, возникающих во время определения грани, за которой рациональные 
фризические и эмоциональные нагрузки становятся чрезмерными, понятие этой чрезмерности представляется крайне важным для врача. Поэтому важнейшая задача спортивной кардиологии состоит в умении контролировать и четко определять допустимый объем и интенсивность тренировочных и соревновательных нагрузок [10].

Возникновение патологических состояний у спортсменов объясняется тем, что физические и эмоциональные нагрузки очень часто превышают их возможности и становятся чрезмерными. Это, по мнению большинства исследователей, является ведущим этиологическим фактором возникновения нарушения метаболизма в миокарде, что приводит к КМПФП. Весьма неоднозначное представление сложилось у ученых в отношении состояния фризической работоспособности у спортсменов с КМПФП. Многие авторы считают, что чаще всего она развивается у спортсменов, тренирующихся на выносливость, объясняя это наличием условий для длительной гиперфункции сердца, аналогичной при патологии, что способствует развитию патологической гипертрофии миокарда с последующей дистрофией.

Использование неадекватных тренировочных нагрузок, а также чрезмерное фрорсирование сроков подготовки квалифицированных спортсменов может привести к различным отклонениям в состоянии кардио- или гемодинамики и закончиться срывом адаптационных процессов, включая случаи внезапной смерти. Однако компенсаторные возможности организма позволяют спортсмену не только тренироваться, но и улучшать спортивные результаты. При этом Г. Л. Апанасенко [1] считает, что для спортсмена обычное явление - иметь отклонения от нормы, а лучшим показателем его здоровья является спортивный результат.

Такая кардиомиопатия продолжает оставаться одним из самых частых заболеваний и, по мнению Л. А. Бутченко [5], встречается у каждого девятого спортсмена, а по данным А. Г. Дембо и Э. В. Земцовского [8], Ф. А. Иорданской [12], Н. В. Махаровой [13], Ю. С. Чистяковой [22] от 6 до $20 \%$ обследованных имеют эту болезнь.

Наиболее характерные диагностические признаки КМПФП - это уплощение, двугорбость, двухфазность или инверсия зубца Т, снижение или куполообразный подъем сегмента ST от изолинии. В зависимости от локализации патологического процесса в миокарде эти изменения регистрируются в соответствующих отведениях ЭКГ. Однако указанные признаки не специфичны в отношении КМПФП. Они встречаются при таких заболеваниях, как ишемическая болезнь сердца, перикардит, инфекционный миокардит, верхушечная форма гипертрофической кардиомиопатии, нарушения электролитного обмена, миокардиодистрофии другого генеза (на фоне анемии, хронического тонзиллита и др.) [2].

До настоящего времени отсутствует единая концепция возникновения КМПФП, поэтому и затруднена ее ранняя диагностика. В то же время существует опасность гипердиагностики КМПФП. Имеются работы, в которых авторы предлагают функциональные пробы с фризической нагрузкой для диагностики КМПФП. По данным 3. Б. Белоцерковского [3], у спортсменов с изменениями конечной части желудочкового комплекса на ЭКГ, вследствие хронического физического перенапряжения, проба с фризической нагрузкой в 60-80\% случаев оказывает нормализующее или различно выраженное положительное влияние. Это свидетельствует о менее выраженных изменениях в миокарде по сравнению с теми случаями, когда отмечается отрицательная динамика зубцов Т [20].

Остается по-прежнему нерешенным вопрос дифореренциальной диагностики дистрофических изменений сердечной мышцы и признаков некроза миокарда. Согласно С. А. Душанину [9], неадекватные физические нагрузки у спортсменов приводят к падению эффективности субэндокардиального кровотока и развитию ишемии миокарда вплоть до некроза. В то же время данные авторов [34] свидетельствуют о том, что у спортсменов с ростом уровня тропонина Т на финише марафонской дистанции и подозрением на инфраркт миокарда, по данным сцинтиграфрии, не были обнаружены зоны некроза миокарда. Полученные результаты позволили авторам прийти к выводу, что повышение уровня тропонина Т у марафонцев под влиянием чрезмерных нагрузок обусловлено глубокими дистрофическими изменениями в сердечной мышце.

Решение задач ранней диагностики патологических состояний КМПФП с признанием полипатогенетической природы, усовершенствованием критериев инструментального и биохимического подтверждения - актуальная проблема не только современной спортивной медицины, но и весьма важное медико-социальное явление современности.

Сегодня делаются попытки усовершенствовать инструментальную диагностику метаболической КМП фризического перенапряжения методами биохимического определения лактатдегидрогеназы и креатинкиназы [18], тропонина 
[28, 32]. Основанием для использования в качестве диагностического теста тропонина I послужили данные о том, что для тропонинов отношение концентрации внутримышечных клеток к концентрации в плазме крови намного выше, чем для ферментов и миоглобина, что делает эти белки высокочувствительными маркерами минимального поражения миокарда. Согласно данным [25], применение в клинической практике кардиомаркера должно отвечать определенным характеристикам: 100 \%-ная кардиоспецифичность, отсутствие его в кровотоке в норме или присутствие в минимальных концентрациях, стабильность при хранении, легкость определения, достаточная валидность значений маркера в клинической практике. Всем перечисленным условиям отвечают тропонины.

Тропонин - универсальный для поперечнополосатой мускулатуры белок, локализующийся на тонких миофиламентах ее сократительного аппарата [31]. Тропониновый комплекс, регулирующий процесс мышечного сокращения в кардиомиоцитах, состоит из трех субъединиц: Т, I и С [36]. Первые две - Т и I - существуют в специфичных для миокарда изоформах, отличающихся от изофрорм скелетных мышц [24]. У здоровых лиц тропонины в крови не обнаруживаются [26], а при развитии некроза их содержание в пораженной ткани снижается вследствие «вымывания». Стоит напомнить, что тропонины не являются ранними биомаркерами острого инфраркта миокарда, возрастание уровня сердечных тропонинов отмечается через 4-6 часов, достигая пика в пределах 12-24 часов, что делает их удобными для поздней диагностики ИМ $[25,36]$. Среди многих кардиомаркеров некроза клеток сердца тропонины Т и I показали самую высокую чувствительность и кардиоспецифичность [24, 26, 36], поэтому оценка содержания в крови сердечных тропонинов является «золотым стандартом» в диагностике острого инораркта миокарда (ОИМ) и определении минимального поражения миокарда [6, 21, 36].

Наши первые работы [7, 15-17], посвященные диагностике КМПФП по результатам велоэргометрического тестирования и парных тропонинов у спортсменов, относятся к 2006 году, когда повторный забор крови проводился нами спустя 24 часа после тестирующей велоэргометрической нагрузки. В то же время имеются работы, авторы которых [14] у спортсменов с нарушением процессов реполяризации в миокарде обнаружили достоверное увеличение уровня сердечного тропонина сразу после максимального нагрузочного теста. Несколько ранее А. В. Смоленский и соавт. [19] сообщали, что у спортсменов при длительных чрезмерных фризических нагрузках может отмечаться кратковременный подъем концентрации тропонинов, нормализующийся через 24 часа. Авторы считают, что повышение концентрации тропонина I в основном происходит у больных с острым повреждением миокарда, но может наблюдаться и при метаболических кардиомиопатиях. Исследования, проведенные авторами [27, 32, 33] показали, что повышение тропонина после интенсивной фризической нагрузки коррелирует с обратимой кардиальной дисфункцией, а также может отражать тонкие повреждения миокарда. Вместе с тем, исследования уровня тропонина у марафронцев продемонстрировали, что даже у спортсменов с изначально положительными результатами уровень тропонина нормализуется в течение 24 часов [29, 30, 35], как сообщают А. В. Смоленский и соавт. [19]. У группы спортсменов с нарушением процессов реполяризации $(\mathrm{n}=11)$ до фризической нагрузки уровень тропонина составлял 0,004 нг・мл ${ }^{-1}$, а после - 0,15 нг• мл ${ }^{-1}$, что, возможно, свидетельствует о микроповреждении миокардиальной ткани. Подобное повышение его уровня является по сути достоверным показателем и действительно говорит о некрозе сердечной мышцы.

Цель работы - на основании данных комплексного электрокардиографического и эхокардиографического обследования, определения динамики уровня тропонина I в ответ на дозированную фризическую нагрузку нами разработан алгоритм диагностики метаболической КМПФП у спортсменов высокого класса.

Комплексное клинико-электрокардиографическое обследование выполнено у 3091 спортсмена высокого класса. Изменения конечной части желудочкового комплекса на ЭКГ в покое выявлены у 199 (6,4%) спортсменов, которым было предложено выполнение субмаксимального теста $\mathrm{PWC}_{170}$, в результате у 47 участников обследования изменения желудочкового комплекса на ЭКГ сохранились и/или усилились. В дальнейшем была предложена физическая нагрузка: 20 - спортсменам в виде нагрузки до порога индивидуальной толерантности, а 27 - в виде субмаксимального теста PWC 170, с определением уровня тропонина I до и спустя 24 часа после нагрузки. Эходопплеркардиография с оценкой показателей сердца в одномерном, двумерном и импульсно-волновом режимах, проводилась на аппарате Sim 5000 Plus (Италия) в состоянии покоя, сразу же после нагрузки и на пятой минуте восстановительного периода. Статистическая обработка произведена методами вариационной 
статистики с помощью пакета программ Statistica 6.0.

Результаты исследования и их обсуждение. Спортсмены первой группы ( $n=20)$, которым была предложена физическая нагрузка (ФН) на велоэргометре до индивидуального порога толерантности, отреагировали разным сдвигом уровня тропонина І, что позволило разделить их на две подгруппы. В первую подгруппу отнесли спортсменов ( $n=15)$, у которых в ответ на ФН наблюдалось недостоверное снижение уровня тропонина I по сравнению с исходной величиной, поэтому мы отнесли их к лицам с пограничным состоянием. Во вторую вошли спортсмены ( $n=5)$ с увеличением уровня тропонина I в пределах референтных значений, их рассматривали как лиц с метаболической КМПФП. Таким образом, при проведении теста до индивидуального порога толерантности метаболическая КМПФП подтверждается только у 25,0 \% спортсменов с изменениями конечной части желудочкового комплекса на ЭКГ.

Нам не удалось довести ни одного спортсмена первой группы до целевой ЧСС. Вероятно, это связано с тем, что тест на велоэргометре не является специфическим для указанных спортсменов (футболистов и прыгунов в воду), и целевой (рекомендуемой) ЧСС невозможно достичь, поскольку продолжение ФН на велоэргометре вызывает выраженную одышку и усталость мышц нижних конечностей.

Стресс-эхо-тест с использованием нагрузок до порога индивидуальной толерантности нагрузки у спортсменов с метаболической КМПФП обнаружил следующие закономерности. Исходные структурно-геометрические показатели ЭхоКГ выявили достоверное увеличение диастолического размера левого желудочка (ЛЖ) на 7,2 \% $(p<0,04)$ и толщины межжелудочковой перегородки в систолу на $15,8 \%$ ( $\%<0,03)$ у спортсменов с метаболической КМПФП, по сравнению с лицами с пограничными состояниями. Полученные данные свидетельствуют о большей степени дилатации полости ЛЖ, а также гипертрофиии и гиперкинезии межжелудочковой перегородки (МЖП) при наличии метаболической КМПФП. При оценке систолической фрункции ЛЖ мы не обнаружили достоверных различий показателей фрракции изгнания и переднезаднего укорочения ЛЖ у спортсменов с метаболической КМПФП и пограничными состояниями. Сократимость миокарда ЛЖ, несмотря на наличие патологии, сохраняется на достаточно высоком уровне. Фракция изгнания у спортсменов с метаболической КМПФП и пограничными состояниями составляла 68,0 \%. Диастолическая функция ЛЖ у спортсменов с метаболической КМПФП характеризуется «рестриктивным» наполнением, для которого присуще резкое увеличение линейной скорости раннего наполнения и уменьшение линейной скорости предсердной систолы, что сопровождается увеличением соотношения VE/VA более 2,0 отн.ед. Так, у спортсменов с метаболической КМПФП наблюдалось достоверное увеличение линейной скорости кровотока в период раннего наполнения на 22,9\% $(p<0,0003)$ и снижение линейной скорости предсердной систолы на 20,6 \% (р < 0,004), по сравнению со спортсменами с пограничными состояниями. Соотношение VE/VA у спортсменов с метаболической КМПФП составило 2,96 \pm 0,20, а у спортсменов с пограничными состояниями 1,99 $\pm 0,08$ отн.ед. Таким образом, в состоянии покоя у лиц с метаболической КМПФП имело место «рестриктивное» наполнение, а у спортсменов с пограничными состояниями - «псевдонормальное». Показатели гемодинамики малого круга кровообращения в обеих группах достоверно не отличались.

На пике фризической нагрузки ЭхоКГ-показатели выявили следующие особенности. У спортсменов с метаболической КМПФП наблюдалось существенное увеличение систолического размера полости левого предсердия (ЛП) на $32,9 \%$ ( $<<0,03)$, уменьшение толщины межжелудочковой перегородки в диастолу на 12,7 \% $(p<0,03)$ и тенденция к увеличению толщины межжелудочковой перегородки в систолу, что является отражением ее гиперкинеза. По показателям систолической и диастолической функции левого и правого желудочков группы спортсменов не различались.

В восстановительном периоде у спортсменов с метаболической КМПФП преобладал систолический размер полости ЛП на 5,4 \% (р < 0,03) по сравнению с аналогичным показателем у спортсменов с пограничными состояниями. Достоверные различия между группами обнаружены по показателям диастолической фрункции ЛЖ. Так, у спортсменов с метаболической КМПФП наблюдалось существенное увеличение времени замедления потока раннего наполнения ЛЖ на $25,2 \%$ ( $<0,02)$, скорости раннего наполнения ЛЖ на 40,3\% (р $<0,0001)$, соотношения линейных скоростей раннего наполнения и предсердной систолы VE/VA на 43,9\% ( $<<0,01)$ и укорочение времени изоволюмического расслабления IVRT на 27,8 \% (р < 0,03), по сравнению с теми, которые имели пограничное состояние. Полученные в восстановительном 
периоде данные у спортсменов с метаболической КМПФП отражают увеличение жесткости миокарда ЛЖ и формирование «рестриктивного» профиля наполнения левого желудочка.

Сопоставление исходных показателей ЭхоКГ со значениями на пике нагрузки у спортсменов с метаболической КМПФП выявило достоверное укорочение временных показателей RVET на $20,0 \%$ ( $<<0,02)$, увеличение линейной скорости трансмитрального кровотока в период систолы предсердия на 74,2 \% (p<0,009), прирост фрракции переднезаднего укорочения ЛЖ на 23,3\% ( $<<0,04)$, снижение индекса соотношения максимальных скоростей VE/VA на 51,0\% ( $<<0,0005)$ и интегральных скоростей IE/IA на $54,3 \%(p<0,01)$.

Таким образом, при проведении теста до порога индивидуальной толерантности у спортсменов с метаболической КМПФП ЭхоКГ на пике нагрузки позволяет выявить увеличение систолической функции ЛЖ, изменение профиля диастолического наполнения ЛЖ с «рестриктивного» на «псевдонормальный» за счет увеличения вклада ЛП и укорочения времени изгнания в легочной артерии.

При сравнении исходных данных ЭхоКГ и показателей, зарегистрированных в восстановительном периоде, у спортсменов с метаболической КМПФП обнаружены достоверные различия временных показателей. Исходные интервалы IVRT значительно превосходят аналогичные интервалы в период восстановления на 27,7 \% (р < 0,002). У спортсменов с метаболической КМПФП исходная толщина межжелудочковой перегородки в систолу существенно превышала ее систолическую толщину в период восстановления на $17,9 \%$ ( $<<0,03)$. Таким образом, в восстановительном периоде после ФН до порога индивидуальной толерантности у спортсменов с метаболической КМПФП наблюдается снижение систолического утолщения межжелудочковой перегородки. В восстановительном периоде, по сравнению с исходным состоянием у спортсменов с метаболической КМПФП, отмечается достоверное увеличение линейной скорости трансмитрального кровотока в период предсердной систолы на 39,4 \% (р < 0,003), снижение соотношения линейных скоростей VE/VA на $28,0 \%$ (р < 0,01) и интегральных скоростей IE/IA на 45,5\% ( $\%<0,01)$. Полученные данные указывают на уменьшение степени диастолической дисфункции в восстановительном периоде, однако профиль наполнения сохраняется «рестриктивным», как и в исходном состоянии.
Сравнение параметров, зарегистрированных на пике нагрузки и в восстановительном периоде, у спортсменов с метаболической КМПФП характеризовалось тенденцией к снижению фракции выброса и переднезаднего укорочения ЛЖ, достоверно меньшей линейной скоростью кровотока в легочной артерии на 18,2\% $(p<0,02)$ и большим соотношением линейных скоростей трансмитрального кровотока в период раннего наполнения ЛЖ к систоле левого предсердия VE/VA на 46,9 \% (р < 0,01) в восстановительном периоде. Динамика указанных показателей в восстановительном периоде у этих спортсменов свидетельствует о возврате к «рестриктивному» наполнению и снижении систолической функции левого и правого желудочков.

Аналогичным образом были распределены спортсмены, у которых в ответ на субмаксимальный тест $\mathrm{PWC}_{170}$ также наблюдалось разнонаправленное изменение концентрации тропонина I в плазме. В первую подгруппу (с пограничным состоянием) отнесли спортсменов, у которых в ответ на субмаксимальный тест PWC $_{170}$ уровень тропонина I не изменялся или недостоверно снижался по сравнению с исходной величиной (n = 20), а во вторую подгруппу (с метаболической КМПФП) - спортсменов с увеличением уровня тропонина I в пределах рефрерентных значений $(\mathrm{n}=7)$. Таким образом, при проведении субмаксимального теста PWC 170 метаболическая КМПФП подтверждается только у 25,9 \% спортсменов с изменениями конечной части желудочкового комплекса на ЭКГ.

Исходные структурно-геометрические показатели ЭхоКГ выявили тенденцию к увеличению полости ЛП во время систолы ЛЖ и достоверное увеличение диастолического размера ЛЖ на $6,4 \%(p<0,05)$ у спортсменов с метаболической КМПФП. Появление дилатации полости ЛП и ЛЖ у лиц, имеющих миокардиальную патологию некоронарогенного генеза, согласуется с современными представлениями о механизмах развития данного патологического процесса и отражает ремоделирование сердца.

У спортсменов с метаболической КМПФП нами не выявлено дилатации полости правого желудочка (ПЖ). По данным С. А. Бондарева [4], для метаболической КМПФП характерно расширение не только полости ЛП, но и полости ПЖ. Автором было показано, что у спортсменов с аритмической фрормой клинического течения метаболической КМПФП размеры ЛП и ПЖ достоверно больше, чем у спортсменов контрольной группы. Наиболее вероятной причиной 
дилатации левого и правого желудочков может быть увеличение жесткости миокарда ЛЖ.

При оценке систолической функции ЛЖ нами не обнаружено достоверных различий показателей фракции изгнания и переднезаднего укорочения ЛЖ у спортсменов с метаболической КМПФП и пограничными состояниями. Необходимо подчеркнуть, что сократимость миокарда ЛЖ, несмотря на наличие патологии, остается на достаточно высоком уровне. Фракция изгнания у спортсменов с метаболической КМПФП и пограничными состояниями составляла 68,073,0 \%. Диастолическая функция ЛЖ исходно характеризовалась недостоверно большими значениями линейных скоростей кровотока в период раннего наполнения и в период систолы ЛП у спортсменов с метаболической КМПФП. В обеих группах спортсменов (с КМПФП и пограничными состояниями) имели место значения индекса VE/VA больше 2,0, что является критерием нарушения диастолического наполнения ЛЖ по «рестриктивному» типу. Различия индекса соотношения линейных скоростей VE/VA между группами спортсменов с метаболической КМПФП и пограничными состояниями были несущественными, однако индексы соотношения интегральных скоростей IE/IA достигли порога статистической значимости $\mathrm{p}<0,03$. При этом индекс в группе с метаболической КМПФП был на 42,9 \% больше, чем в референтной группе. Таким образом, можно утверждать, что степень нарушений диастолического наполнения ЛЖ более выражена у спортсменов с метаболической КМПФП.

При анализе особенностей кровотока в системе малого круга кровообращения обнаружена тенденция к снижению линейной скорости и одинаковые интегральные скорости кровотока в легочной артерии у спортсменов с метаболической КМПФП и с пограничными состояниями. Выравнивание интегральных скоростей кровотока в обеих группах спортсменов достигается за счет достоверного увеличения времени изгнания в легочной артерии у лиц с метаболической КМПФП на 15,3 \% ( $<<0,04)$. В данном случае удлинение периода изгнания из правого желудочка может служить не только проявлением приспособительной реакции правого желудочка, направленной на сохранение объемной скорости кровотока в легочной артерии, но и отражением его систолической дисфункции. Аналогичные данные получены в исследовании [23]. Период напряжения правого желудочка сердца у здоровых спортсменов составлял 0,10 с, а у спортсменов с метаболической КМПФП - 0,24 с. Авторы также считают, что значительное удлинение периода напряжения правого желудочка сердца у спортсменов с метаболической КМПФП указывает на нарушение сократительной способности миокарда [23]. А. С. Иванова [11] придерживается точки зрения, согласно которой, метаболическая КМПФП у спортсменов сопровождается нарушениями сократительной функции не только левого, но и правого желудочков. Таким образом, исходные структурно-геометрические и функциональные показатели сердца у спортсменов с метаболической КМПФП характеризуются достоверным увеличением полости ЛЖ, тенденцией к дилатации ЛП, нарушением диастолического наполнения ЛЖ «рестриктивного» типа и снижением сократимости миокарда правого желудочка (удлинением времени изгнания из правого желудочка) при сохраненной систолической функции ЛЖ.

Структурно-геометрические показатели на пике ФН характеризовались достоверным увеличением диастолического размера полости ЛП на $12,5 \%$ ( $<<0,03)$, конечного диастолического размера ЛЖ на $11,5 \%$ ( $<<0,03)$ у спортсменов с метаболической КМПФП по сравнению со спортсменами с пограничными состояниями. У лиц с метаболической КМПФП на пике фризической нагрузки отмечалась тенденция к преобладанию толщины межжелудочковой перегородки как в систолу, так и в диастолу, над аналогичным показателем в группе спортсменов с пограничными состояниями. Показатели систолической функции ЛЖ в группе с метаболической КМПФП на пике нагрузки не отличались от соответствующих показателей у спортсменов с пограничными состояниями. Диастолическая функция ЛЖ отмечалась выравниванием показателей линейной скорости кровотока в период систолы ЛП в обеих группах спортсменов. Сохранялась тенденция к преобладанию линейной скорости кровотока в период раннего наполнения индекса VE/VA в группе спортсменов с метаболической КМПФП. В обеих группах наблюдалось снижение соотношения VE/VA менее 2,0, что указывает на переход «рестриктивного» типа диастолического наполнения в «псевдонормальный» профиль наполнения на пике нагрузки. Кровоток в легочной артерии характеризовался достоверным преобладанием интегральной скорости в группе спортсменов с метаболической КМПФП на 25,3 \%. Временные показатели кровотока в легочной артерии в обеих группах на пике ФН не имели достоверных отличий.

Таким образом, на высоте ФН у спортсменов с метаболической КМПФП сохраняется дилатация 
полостей ЛП и ЛЖ, преобладают нарушения диастолической функции ЛЖ и отсутствуют различия показателей систолической функции левого и правого желудочков.

Анализ структурно-геометрических показателей у спортсменов с метаболической КМПФП на пятой минуте восстановительного периода выявил тенденцию к увеличению систолического и диастолического размеров ЛП, диастолического размера ЛЖ, систолической и диастолической толщины задней стенки ЛЖ и достоверное преобладание систолической толщины межжелудочковой перегородки на 20,3 \% (р < 0,03), по сравнению с аналогичными показателями в группе спортсменов с пограничными состояниями. По показателям систолической функции ЛЖ группы спортсменов достоверных различий не имели. Диастолическая функция ЛЖ у спортсменов с метаболической КМПФП на пятой минуте восстановительного периода характеризовалась существенным преобладанием индекса соотношения линейных скоростей раннего наполнения и систолы левого предсердия VE/VA на 22,9\% $(p<0,05)$ над аналогичным показателем у спортсменов с пограничними состояниями. При этом абсолютные значения индекса соотношения линейных скоростей раннего наполнения и систолы левого предсердия VE/VA у спортсменов с метаболической КМПФП превышали величину 2,0 , а в группе спортсменов с пограничными состояниями находились в диапазоне 1,0-2,0, что свидетельствует о большей степени нарушений диастолического наполнения у спортсменов с метаболической КМПФП.

Если у спортсменов с метаболической КМПФП диастолическая дисфункция ЛЖ может классифрицироваться как «рестриктивный» тип, то у спортсменов с пограничными состояниями «псевдонормальное» наполнение. Параметры транспульмонального кровотока на пятой минуте восстановительного периода в группах спортсменов достоверных различий не имели. Таким образом, в восстановительном периоде после субмаксимального теста PWC ${ }_{170}$, структурногеометрические и фрункциональные показатели сердца у спортсменов с метаболической КМПФП характеризуются гипертрофией и гиперкинезией межжелудочковой перегородки и «рестриктивным» профилем диастолического наполнения лЖ.

Сопоставление исходных показателей ЭхоКГ со значениями на пике ФН у спортсменов с метаболической КМПФП выявило достоверное укорочение RVET на 15,4 \% ( $<<0,001)$ и увеличение линейной скорости кровотока в легочной артерии на 28,1 \% (р $<0,009)$. Достоверные различия коснулись только временных показателей при сравнении исходных данных ЭхоКГ и показателей, зарегистрированных в восстановительном периоде у спортсменов с метаболической КМПФП. Исходный интервал RVET существенно больше аналогичного интервала в период восстановления на $10,9 \%$ ( $<<0,004)$.

Сравнение параметров, зарегистрированных на пике ФН и на пятой минуте восстановительного периода, характеризовались у спортсменов с метаболической КМПФП достоверно меньшей линейной на $11,6 \%(p<0,05)$ и интегральной на $25,0 \%(p<0,05)$ скоростью кровотока в период раннего наполнения ЛЖ, линейной на $21,9 \%(p<0,05)$ и интегральной на $25,3 \%$ $(p<0,05)$ скоростью кровотока в легочной артерии в восстановительном периоде. Таким образом, в этом периоде после ФН у спортсменов с метаболической КМПФП наблюдается возврат к «рестриктивному» профилю наполнения ЛЖ и снижению систолической фрункции правого желудочка.

\section{Выводы}

1. Электрокардиографические изменения у спортсменов с метаболической КМП физического перенапряжения и пограничными состояниями неспецифичны, имеют фракультативный характер и позволяют проводить только первичный скрининг для выделения лиц с подозрением на патологию миокарда из общего числа обследованных.

2. Структурно-геометрические и функциональные показатели сердца, измеренные до выполнения нагрузочных тестов у спортсменов с КМПФП, характеризуются дилатацией полости ЛЖ, тенденцией к дилатации ЛП, гипертрофией и гиперкинезией МЖП, сохраненной систолической функции ЛЖ, снижением сократимости миокарда ПЖ и нарушением диастолического наполнения ЛЖ по «рестриктивному» типу.

3. Общими закономерностями структурногеометрических и фрункциональных сдвигов у спортсменов с КМПФП на пике нагрузки при проведении нагрузочных тестов являются дальнейшая дилатация ЛП, трансформация «рестриктивного» профиля диастолического наполнения ЛЖ в «псевдонормальный», восстановление систолической фрункции ПЖ. На пике нагрузки (тест $\mathrm{PWC}_{170}$ ) у спортсменов с КМПФП остается стабильной систолическая функция ЛЖ за счет дилатации полости, а при проведении теста до порога индивидуальной толерантности наблюдается увеличение систолической функции ЛЖ и гиперкинезия МЖП. 
4. В восстановительном периоде после субмаксимального теста $\mathrm{PWC}_{170}$ структурно-геометрические и функциональные показатели деятельности сердца у спортсменов с КМПФП характеризуются гипертрофией и гиперкинезией МЖП и возвратом к «рестриктивному» профиилю диастолического наполнения ЛЖ, а после теста до порога индивидуальной толерантности у спортсменов с КМПФП наблюдается увеличение систолического размера полости ЛП, возврат к «рестриктивному» наполнению ЛЖ и снижение систолической функции ПЖ.

5. Диагностическая чувствительность стрессэхо-тестов с применением субмаксимального теста PWC $_{170}$ и до порога индивидуальной толерантности в сочетании с парными тропонинами I сопоставима и составляет соответственно 25,9 и 25,0 \%. Наиболее чувствительным

\section{Литература}

1. Апанасенко Г. Здоровье спортсменов / Г. Апанасенко // Наука в олимп. спорте. - 2000. - № 1. - С. 92-96.

2. Аринчин Н. И. Длительные наблюдения за спортсменами с дистрофрией миокарда вследствие физического перенапряжения / Н.И.Аринчин, М. К. Фекета //Вопросы спортивной кардиологии. - М., 1977. - С. 53-59.

3. Белоцерковский 3. Б. Эргометрические и кардиологические критерии фризической работоспособности у спортсменов / З. Б. Белоцерковский. - М.: Сов. спорт, 2005. 312 c.

4. БондареВ С. А. Аритмический вариант клинического течения дистрофии миокарда у спортсменов: автореф. дис. на соискание учен. степени канд. мед. наук / С. А. Бондарев. - СПб., 1994. - 22 с.

5. Бутченко Л. А. Опыт профилактики дистрофии миокарда у спортсменов / Л. А. Бутченко, С. С. Абрамова, М.П.Дунаева, В. Л. Бутченко // Теория и практика фриз. культуры. - 1989. - № 1. - С. 18-19.

6. Габуния М. Биохимические маркеры некроза миокарда / М. Габуния // Врач. - 2004. - № 1. С. $56-57$.

7. Деклараційний патент на корисну модель №13926 «Спосіб комплексної діагностики дистрофії міокарда внаслідок фрізичного перенапруження у спортсменів» / Михалюк Є. Л., Сиволап В. В. Промислова власність. Бюл. № 4, 2006. -4 с.

8. Дембо А. Г. Спортивная кардиология: Руководство для врачей / А. Г. Дембо, Э. В. Земцовский. - Л.: Медицина, 1989. -464 с.

9. Душанин С. А. Хроническое перенапряжение сердца у спортсменов: соотношение между снабжением и потреблением кислорода миокардом / С. А. Душанин // Актуальные вопр. спорт. мед.: материалы республ. научн.практ. конф. - К., 1980. - С. 211-212.

10. ЗемиоВский Э. В. Спортивная кардиология / Э. В. Земцовский. - СПб.: Гиппократ, 1995. - 448 с.

11. ИВаноВа А. С. Кардиодинамика правого и левого желудочков сердца в состоянии покоя и после физических нагрузок у спортсменов с дистрофией миокарда вследствие физического перенапряжения / А. С. Иванова // Вопросы спортивной кардиологии. - М., 1977. - С. 11-21. диагностическим эхокардиографрическим маркером КМПФП у спортсменов является диастолический профиль наполнения ЛЖ.

6. Достоверность диагностики значительно повышается при дополнительном использовании эходопплеркардиографрии, а также (с учетом требований биоэтики) субмаксимального теста $\mathrm{PWC}_{170}$ - вместо фризической нагрузки до порога индивидуальной толерантности, с определением динамики тропонинов І. Данные спортивно-медицинской литературы свидетельствуют о встречаемости КМПФП у спортсменов в 20-22 \% случаев, тогда как, по нашим данным, их всего 0,39\%.

Перспективы дальнейших исследований связаны с совершенствованием методик ранней диагностики метаболической кардиомиопатии вследствие хронического фризического перенапряжения у спортсменов.

\section{References}

1. Apanasenko G. Health of sportsmen / G. Apanasenko // Science in the Olympic sport. - 2000. - N. 1. - P 9296.

2. Arinchin N. I. Long-term monitoring of athletes with myocardial dystrophy due to physical overstrain / N. I. Arinchin, M. K. Feketa // Questions of sports cardiology. - Moscow. 1977. - P. 53-59.

3. Belotserkovsky Z. B. Ergometric and cardiac criteria of physical performance in athletes / Z. B. Belotserkovsky. Moscow: Sovietsky Sport. - 2005. - 312 p.

4. Bondarev S. A. Arrhythmic version of the clinical course of myocardial dystrophy in athletes: Author. diss ... Candidate of medical sciences / S. A. Bondarev. - Saint-Petersburg, 1994. $22 \mathrm{p}$.

5. Butchenko L. A. Experience in prevention of myocardial dystrophy in athletes / L. A. Butchenko, S. S. Abramova, M. P. Dunaeva, V. L. Butchenko // Theory and Practice of Physical Culture. -1989. - N. 1. - P. 18-19.

6. Gabuniya M. Biochemical markers of myocardial necrosis / M. Gabuniya // Doctor. - 2004. - N. 1. - P. 56-57.

7. Patent for useful model № 13926 «Method for comprehensive diagnostics of myocardial dystrophies a result of physical strain in athletes» / E. L. Mikhalyuk, V. V. Syvolap. Industrial Property, Bull. N 4. - 2006. - 4 p.

8. Dembo A. G. Sports Cardiology: Guide for doctors / A. G. Dembo, E. V. Zemtsovsky. - Leningrad: Medicina. 1989. -464 p.

9. Dushanin S. A. The chronic overwork of the heart in athletes: the relationship between supply and myocardial oxygen consumption / S. A. Dushanin // Actual problems of sports medicine: Materials of republican scientific. and practical. conference. - Kiev, 1980. - P. 211-212.

10. Zemtsovsky E. V. Sports Cardiology / E. V. Zemtsovsky. Saint-Petersburg: Hippocrates. - 1995. - 448 p.

11. Ivanova A. S. Cardiodynamics right and left ventricles of the heart at rest and after physical activity in athletes with myocardial dystrophia due to physical overexertion / A. S. Ivanova // Questions of sports cardiology. - Moscow, 1977. - P. 11-21.

12. lordanskaya F. A. Morphological and functional possibilities of women in long-term adaptation to the loadings of 
12. Иорданская Ф. А. Морфофункциональные возможности женщин в процессе долговременной адаптации к нагрузкам современного спорта / Ф. А. Иорданская //Теория и практика фриз. культуры. - 1999. - № 6. - С. 43-50.

13. Махарова Н. В. Диагностика физического перенапряжения сердечно-сосудистой системы у спортсменов-единоборцев / Н. В. Махарова // Междунар. научн. конф. «Состояние и перспективы развития медицины в спорте высших достижений «СпортМед-2006». - М., 2006. - С. 185, 186.

14. Михайлова A. B. Методы оценки и повышения работоспособности у спортсменов / А. В. Михайлова, А. В. Смоленский / / Материалы Всерос. науч.-практ. конф. с междунар. участием. - СПб., 2013. - С. 54-57.

15. Михалюк Є. Л. Варіабельність серцевого ритму і динаміка тропоніну I при дистрофії міокарда внаслідок фізичного перенапруження / Є. Л. Михалюк // Мед. перспективи. - 2006. - Т. XI, № 1. -С. 106-110.

16. Михалюк Е. Л. Изменение структурно-геометрических, функциональных показателей сердца и содержания тропонина I при метаболической кардиомиопатии вследствие физического перенапряжения у футболистов высокого класса / Е. Л. Михалюк, В. В. Сыволап // Буковин. мед. вісник. - 2006. - Т. 10, № 1. - С. 43-46.

17. Михалюк Е. Л. Диагностическая чувствительность нагрузочного тестирования, эхокардиография и динамика тропонинов I у спортсменов высокого класса в верификации метаболической кардиомиопатии физического перенапряжения / Е. Л. Михалюк, В.В.Сыволап // Патологія. 2007. - T. 4, №1. - С. 62-66.

18. Новиков A. A. Стратегия подготовки сборной команды Российской Федерации к Олимпийским играм 2004 и 2008 г. / А. А. Новиков, Ю. А. Ипполитов, С. В. Соколова // Теория и практика фриз. культуры. - 2002. № 1. - С. 32-34.

19. Смоленский $A$. В. Кардиальные тропонины и нарушение реполяризации у спортсменов / А. В. Смоленский, А. В. Михайлова, Б. А. Никулин, Е. В. Ухлина // Лечеб. оризкультура и спорт. медицина. - 2010. - № 9. - С. 26-28.

20. Спортивное сердце / Л. А. Бутченко, М. С. Кушаковский. - СПб., 1993. - 48 с.

21. Тропонины в кардиологической практике. Пособие для врачей / Шалаев С. В., Петрик Е. С., Панин А. В. - Новосибирск, 2001. - 19 с.

22. Чистякова Ю. Современные аспекты электрокардиографии спортсменов высокой квалификации / Ю. Чистякова / / XI Міжнар. наук.-практ. конф. «Сучасні досягнення спортивної медицини, лікувальної фрізкультури та валеології». Одеса, 2005. - С. 221-226.

23. Яковлев Е. Ф. Гемодинамика печени у спортсменов с дистрофией миокарда / Е. Ф. Яковлев, Р. Д. Дибнер // Теория и практика фриз. культуры. - 1983. - № 8. C. $13-14$.

24. Apple F. S. Expression of cardiac troponin T isoforms in skeletal muscle of renal patients with not cause falsepositive serum results by second generation cardiac troponin T assays / F. S. Apple, V. Ricchiuti, E. M. Voss et al. / / Eur. J. Cardiol. -1998. - Vol. 19. - Suppl. N: 30-33.

25. Collinson P. Troponin T or troponin I or CR-MB (or none?) / P. Collinson //Eur. Heart J. -1998. - Vol. 19. Suppl. N. - P. 16-24.

26. Hartmann F. Biochemical markers in diagnosis of coronary artery disease / F. Hartmann, M. Kampmann, N. Frey et al. / / Eur. Heart J. - 1998. - Vol. 19. - Suppl. N: 2-7.

27. Neilan T. G. Myocardial injury and ventricular dysfunction Related to training levels among non elite participants in the Boston marathon / T. G. Neilan, modern sports / F. A. lordanskaya / / Theory and Practice of Physical Culture. - 1999. - N. 6. - P. 43-50.

13. Maharova N. V. Diagnostics of physical overexertion the cardiovascular system in combat sports athletes / N. V. Maharova // International scientific conference «State and prospects of development of medicine in elite sport SportMed-2006». - Moscow, 2006. - P. 185, 186.

14. Mikhailova $A$. V. Methods for evaluating and improving the performance of athletes / A. V. Mikhailova, A. V. Smolensky // Materials of the Russia. Scientific-practical conference with int. participation, Saint-Petersburg, 2013. P. 54-57.

15. Mikhalyuk E. L. Heart rate variability and dynamics of troponin I in the myocardial dystrophies' due to physical overexertion / E. L. Mikhalyuk // Medical Perspectives. 2006. - Vol. XI, N 1. - P. 106-110.

16. Mikhalyuk E. L. Change of structure-geometric, functional performance of the heart and the content of troponin I in the metabolic cardiomyopathy due to physical overexertion in high class football players / E. L. Mikhalyuk, V. V. Syvolap // Bukovinian Medical Herald. - 2006. - Vol. 10, N 1. P. $43-46$.

17. Mikhalyuk E. L. The diagnostic sensitivity of exercise testing, echocardiography and dynamics of troponin I in athletes of high class in verification of metabolic cardiomyopathy physical overexertion / E. L. Mikhalyuk, V. V. Syvolap // Pathology. - 2007. - Vol. 4, N 1. - P. 62-66.

18. Novikov $A$. $A$. The strategy to train the national team of the Russian Federation for the Olympic Games of 2004 and 2008 / A. A. Novikov, J. A. Ippolitov, S. V. Sokolova // Theory and Practice of Physical Culture. - 2002. - N. 1. P. 32-34.

19. Smolensky A. V. Cardiac troponins and violation of repolarization in athletes / A. V. Smolensky, A. V. Mikhailova, B. A. Nikulin, E. V. Uhlina // Physical therapy and sports medicine, 2010. - N. 9. - P. 26-28.

20. Sports heart / L. A. Butchenko, M. S. Kuszakowski. - Saint-Petersburg, 1993. - 48 p.

21. Cardiac troponins in practice. Manual for doctors / S. V. Shalaev, E. S. Petrik, A. V. Panin. - Novosibirsk. 2001. -19 p.

22. Chistyakova J. Modern aspects of electrocardiography sportsmen of high qualification / J. Chistyakova / / XI Int. scientific and practical Scientific and Practical conf. Modern achievements of sports medicine, physical therapy and valeology. - Odessa, 2005. - P. 221-226.

23. Yakovlev E. F. Hepatic hemodynamics in athletes with myocardial dystrophy / E. F. Yakovlev, R. D. Dibner // Theory and Practice of Physical Culture. - 1983. - Vol. 8. P. 13-14.

24. Apple F. S. Expression of cardiac troponin $\mathrm{T}$ isoforms in skeletal muscle of renal patients with not cause false-positive serum results by second generation cardiac troponin T assays / F. S. Apple, V. Ricchiuti, E. M. Voss et al. / E Eur. J. Cardiol. - 1998. - N. 19. - Suppl. $\mathrm{N}: 30-33$.

25. Collinson $P$. Troponin T or troponin I or CR-MB (or none?) / P. Collinson / / Eur. Heart J. - 1998. - Vol. 19. Suppl. N. - P. 16-24.

26. Hartmann $F$. Biochemical markers in diagnosis of coronary artery disease / F. Hartmann, M. Kampmann, N. Frey et al. // Eur. Heart J. - 1998. - Vol. 19. - Suppl. N: 2-7.

27. Neilan T. G. Myocardial injury and ventricular dysfunction Related to training levels among non elite participants in the Boston marathon / T. G. Neilan, J. L. Januzzi, 
J. L. Januzzi, E. Lee-Lewandrowski et al. // Circulation. 2006; 114. - P. 2325-2333.

28. Neumayr G. Plasma levels of cardiac troponin after prolonged strenuous endurance exercise / G. Neumayr, K. Gaenzer, R. Pfister et al. //Am. J. Cardiol. - 2001. Vol. 87. - P. 369-371.

29. Neumayr G. Effect of competitive marathon cycling on plasma $\mathrm{N}$-terminal probrain natriuretic peptide and cardiac troponin $\mathrm{T}$ in healthy recreational cyclists / G. Neumayr, R. Pfister, G. Mitterbauer et al. // Am. J. Cardiol. - 2005; 96. - P. 732-735.

30. Neumayr G. Effect of the «Race Across The Alps» in elite cyclists on plasma cardiac troponins I and T / G. Neumayr, R. Pfister, G. Mitterbauer et al. //Am. J. Cardiol. - 2002; 89. - P. 484-486.

31. Ohtsuki l. Calcium ion regulation of muscle contraction: the regulatory role of troponin T / I. Ohtsuki // Mol. Cell. Biochem. - 1999. - Vol. 190. - P. 33-38.

32. Rifai N. Cardiac troponin T and I, electrocardiographic wall motion analysis and ejection fractions and athletes participating in the Hawaii Jronman Triathlon / N. Rifai, P. S. Douglas, M. O'Toole et al. / / Am. J. Cardiol. - 1999. Vol. 83. - P. 1085-1089.

33. Shave $R$. Exercise-induced cardiac troponin $T$ release: meta-analysis / R. Shave, K. P. George, G. Atkinson et al. // Med. Sci Sports Exerc. - 2007; 39. - P. 2099-2106.

34. Siegel A. J. Normal post-race antimyosin myocardial scintigraphy in asymptomatic marathon runners with elevated serum creatine kinase $M B$ isoenzyme and troponin $T$ levels. Evidence against silent myocardial cell necrosis / A. J. Siegel, K. B. Lewandrowski, H. W. Strauss, A. J. Fischmann, T. Yasuda // Cardiology. -1995. - Vol. 86 (6). - P. 451-456.

35. Tian $Y$. Cnanges in serum cardiac troponins following a 21-km run in junior male runners / Y. Tian, J. Nie, T. K. Tong et al // J. Sports Med. Phys. Fitness. - 2006; 46. - P. 481488.

36. Wu A. H. B. Biochemical differences between cTnT and $\mathrm{cTnl}$ and their significance for diagnosis of acute coronary syndromes / A. H. B. Wu, Y. J. Feng // Eur. Heart J. 1998. - Vol. 19. - Suppl. N: 25-29.
E. Lee-Lewandrowski et al. // Circulation. 2006; 114. P. 2325-2333.

28. Neumayr G. Plasma levels of cardiac troponin I after prolonged strenuous endurance exercise / G. Neumayr, K. Gaenzer, R. Pfister et al. // Am. J. Cardiol. - 2001. Vol. 87. - P. 369-371.

29. Neumayr G. Effect of competitive marathon cycling on plasma $\mathrm{N}$-terminal probrain natriuretic peptide and cardiac troponin $\mathrm{T}$ in healthy recreational cyclists / G. Neumayr, R. Pfister, G. Mitterbauer et al. // Am. J. Cardiol. - 2005; 96. - P. 732-735.

30. Neumayr G. Effect of the «Race Across The Alps» in elite cyclists on plasma cardiac troponins I and T / G. Neumayr, R. Pfister, G. Mitterbauer et al. //Am. J. Cardiol. 2002; 89. - P. 484-486.

31. Ohtsuki I. Calcium ion regulation of muscle contraction: the regulatory role of troponin T / I. Ohtsuki // Mol. Cell. Biochem. - 1999. - Vol. 190. - P. 33-38.

32. Rifai N. Cardiac troponin T and I, electrocardiographic wall motion analysis and ejection fractions and athletes participating in the Hawaii Jronman Triathlon / N. Rifai, P. S. Douglas, M. O'Toole et al. //Am. J. Cardiol. -1999. - Vol. 83. P. $1085-1089$.

33. Shave $R$. Exercise-induced cardiac troponin $\mathrm{T}$ release: meta-analysis / R. Shave, K. P. George, G. Atkinson et al. // Med. Sci Sports Exerc. - 2007; 39. - P. 2099-2106.

34. Siegel $A$. J. Normal post-race antimyosin myocardial scintigraphy in asymptomatic marathon runners with elevated serum creatine kinase MB isoenzyme and troponin $T$ levels. Evidence against silent myocardial cell necrosis / A. J. Siegel, K. B. Lewandrowski, H. W. Strauss, A. J. Fischmann, T. Yasuda // Cardiology. - 1995. - Vol. 86 (6). - P. 451-456.

35. Tian $Y$. Cnanges in serum cardiac troponins following a 21-km run in junior male runners / Y. Tian, J. Nie, T. K. Tong et al // J. Sports Med. Phys. Fitness. - 2006; 46. - P. 481-488.

36. Wu A. H. B. Biochemical differences between cTnT and $\mathrm{cTnl}$ and their significance for diagnosis of acute coronary syndromes / A. H. B. Wu, Y. J. Feng // Eur. Heart J. -1998 . - Vol. 19. - Suppl. N: 25-29. 